\title{
Article \\ pH Controlled Impedimetric Sensing of Copper(II) Ion Using Oxytocin as Recognition Element
}

\author{
Kiran Kumar Tadi, Israel Alshanski, Mattan Hurevich $\$ and Shlomo Yitzchaik * \\ Institute of Chemistry and the Center for Nanoscience and Nanotechnology, \\ The Hebrew University of Jerusalem, Jerusalem 9190401, Israel; chemistkrn@gmail.com (K.K.T.); \\ israel.alshanski@mail.huji.ac.il (I.A.); mattan.hurevich@mail.huji.ac.il (M.H.) \\ * Correspondence: shlomo.yitzchaik@mail.huji.ac.il; Tel.: +972-52-4738075
}

Received: 19 August 2018; Accepted: 11 October 2018; Published: 15 October 2018

\begin{abstract}
We report the modulation of the specific metal gation properties of a peptide and demonstrate a highly selective sensor for copper(II) ion. The neuropeptide oxytocin (OT) is reported for its high affinity towards $\mathrm{Zn}^{2+}$ and $\mathrm{Cu}^{2+}$ at physiological $\mathrm{pH}$. The binding of the metal ions to OT is tuned by altering the $\mathrm{pH}$ of the medium. OT was self-assembled on glassy carbon electrode using surface chemistry, and electrochemical impedance spectroscopy (EIS) was used to probe the binding of $\mathrm{Cu}^{2+}$. Our results clearly indicate that at $\mathrm{pH} 10.0$, the binding of $\mathrm{Cu}^{2+}$ to OT is increased compared to that at $\mathrm{pH} 7.0$, while the binding to $\mathrm{Zn}^{2+}$ becomes almost negligible. This proves that the selectivity of OT towards each of the ions can be regulated simply by controlling the $\mathrm{pH}$ of the medium and hence allows the preparation of a sensing device with selectivity to $\mathrm{Cu}^{2+}$.
\end{abstract}

Keywords: oxytocin; copper(II) ion; impedimetric sensor; surface chemistry

\section{Introduction}

During the past few years, numerous peptide- and protein-based electrochemical sensors have been exploited for the detection of metal ions [1-6]. The selective metal ligation of peptides is derived from the specific amino acids sequence and conformations $[7,8]$. Oxytocin (OT) is a neuro peptide that has an affinity for metal ions and highly conserved mediator of physiological and psychic processes. Binding of OT to different divalent metal ions, notably to $\mathrm{Zn}^{2+}$ or $\mathrm{Cu}^{2+}$, affects its interaction with the receptor, which regulates the signaling pathways either by activation or deactivation $[9,10]$.

In our previous studies, we proved that OT can serve as a recognition element with an affinity towards both $\mathrm{Zn}^{2+}$ and $\mathrm{Cu}^{2+}$ compared to other relevant ions. However, at physiological $\mathrm{pH}$, there was no selectivity between $\mathrm{Zn}$ and $\mathrm{Cu}$ and we had to use masking agents to discriminate between them [11]. OT metal binding takes place through unique mechanisms; at physiological $\mathrm{pH}(7.0), \mathrm{Zn}^{2+}$ forms an octahedral complex through the OT carbonyl oxygens, while $\mathrm{Cu}^{2+}$ forms a square-planar complex via several deprotonated OT amide nitrogens [9]. We opted to take advantage of these differences in the binding mechanism to enable selective sensing of $\mathrm{Cu}^{2+}$ in the presence of $\mathrm{Zn}^{2+}$. We hypothesized that the deprotonation of the OT amides at $\mathrm{pH} 10.0$ will be more preferable and, hence, would lead to enhanced binding to $\mathrm{Cu}^{2+}$ [12]. The $\mathrm{pH}$ effect will also help to eliminate OT affinity towards $\mathrm{Zn}^{2+}$ since, at a higher $\mathrm{pH}$, the formation of $\mathrm{Zn}(\mathrm{OH})_{2}$ is more prominent and hence we turned to OT complex to see if we could use the $\mathrm{pH}$ of the medium for selective sensing of $\mathrm{Cu}^{2+}$ (Figure 1). The immobilization of vertically aligned OT onto glassy carbon electrode (GCE) was conducted using dibenzocyclooctyne as a spacer that avoids the use of $\mathrm{Cu}^{2+}$ for click chemistry, as previously reported [11]. Hence, it facilitates the ease of trace level detection of $\mathrm{Cu}^{2+}$. In this work, we studied OT interaction with $\mathrm{Zn}$ and $\mathrm{Cu}$ at pH 10 using electrochemical impedance spectroscopy (EIS) and compared the selectivity with pH 7.0. We observed an enhanced selectivity of the proposed sensor towards $\mathrm{Cu}^{2+}$ in comparison to $\mathrm{Zn}^{2+}$. 


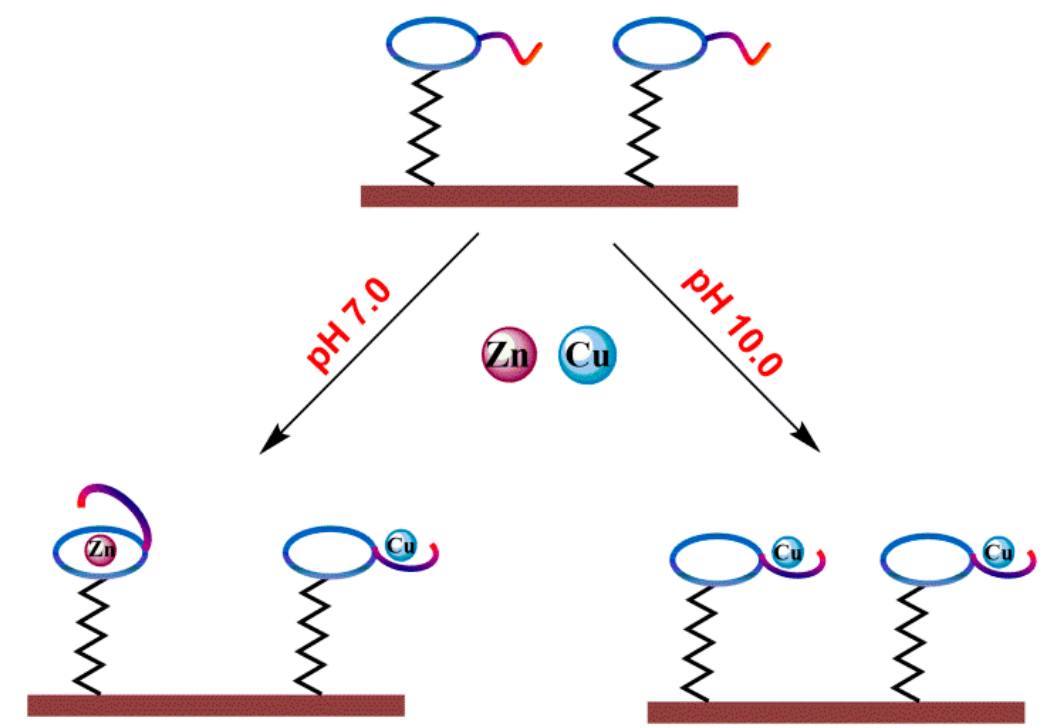

Figure 1. Tuning the binding activity of oxytocin (OT) anchored to the surface by altering the $\mathrm{pH}$ of the medium. OT binds both Zinc and Copper are similar affinity at physiological $\mathrm{pH}$ (left), while OT binds selectively Copper at alkaline $\mathrm{pH}$ (right).

\section{Experimental Section}

\subsection{Material and Methods}

Oxytocin, 3-aminopropyl(triethoxysilane) (APTES), dibenzocyclooctyl- $N$-hydroxysuccinimide (DBCO-NHS) and $N$-(dimethylaminopropyl)- $N$ '-carbodiimide hydrochloride (EDC) were purchased from Sigma-Aldrich, Rehovot, Israel. Ethanol (ACS grade), potassium hexacyanoferrite (III), potassium hexacyanoferrate (II), sodium phosphate dibasic, and sodium phosphate monobasic were purchased from Merck Chemicals (Burlington, MA, USA). All chemicals were AR grade and used without further purification. Aqueous solutions were prepared using Millipore water received from Milli-Q system (Millipore Inc., Burlington, MA, USA). The $\mathrm{pH}$ of the medium was adjusted to 10.0 by gradual addition of $0.1 \mathrm{M} \mathrm{NaOH}$ to phosphate buffer solution. OT functionalized with azide was synthesized by standard microwave-assisted Fmoc solid phase peptide synthesis protocol. Synthesis was performed on solid support with repeating steps of Fmoc removal and amino acids coupling. Fmoc was removed from the amine in a solution of 1:4 piperidine/N-methy 2-pyrrolidone (NMP) and the next protected amino acid coupled with a solution of 1-[bis(dimethylamino)methylene]-1H-1,2,3-triazolo[4,5-b]pyridinium 3-oxid hexaflurophosphate (HATU) as a coupling agent, diisopropylethylamine as the base, and NMP as the solvent. The full sequence of OT cyclized by microwave-assisted disulfide formation in oxidative conditions of Iodine dissolved in $2 \% v / v$ anisole/NMP. Azido acetic acid coupled to the N-terminal part of the OT to give azide functionality for click chemistry. The peptide was cleaved by standard TFA cleavage procedure and purified by preparative HPLC.

\subsection{UV-Visible Spectroscopy Titrations}

Coordination complexes of different $\mathrm{OT}$ to $\mathrm{Cu}^{2+}$ ratio were prepared as follows. Various dilutions of $\mathrm{Cu}^{2+}$ solution were prepared from stock solution of $100 \mu \mathrm{M} \mathrm{Cu}\left(\mathrm{NO}_{3}\right)_{2}(99.999 \%$ trace metal basis) in phosphate buffer solution ( $\mathrm{pH}$ 10.0). OT stock solution of $100 \mu \mathrm{M}$ was prepared in phosphate buffer solution ( $\mathrm{pH}$ 10.0). The stock solution was diluted to a concentration of $10 \mu \mathrm{M}$. Fixed OT concentration of $10 \mu \mathrm{M}$ was added to different concentrations of $\mathrm{Cu}^{2+}$ ca. $10 \mu \mathrm{M}, 20 \mu \mathrm{M}, \ldots, 80 \mu \mathrm{M}$. The well-mixed solutions of coordination complexes were analyzed for UV-visible absorbance spectra (Shimadzu 3101, Kyoto, Japan). 


\subsection{Fabrication of OT-Modified Electrode}

The fabrication process of the OT Sensor was confirmed by following the physical characterization of OT immobilized on silicon wafer in the same manner as the OT Sensor [11]. The protocol uses dibenzocyclooctyne that triggers the click chemistry even in the absence of $\mathrm{Cu}^{2+}$ [13].

Initially, the glassy carbon electrode (GCE) surfaces were thoroughly polished using $0.05 \mu \mathrm{m}$ alumina suspensions on micro cloth pads ( $\mathrm{CH}$ instruments, Austin, TX, USA). Then, the electrodes were sonicated in triple distilled water for $15 \mathrm{~min}$. The cleaned GCE surface was modified with the following steps. Then, the mirror finished hydroxylated GCE (GCE-OH) surface was suspended in $1 \% \mathrm{KOH}$ solution and the solution was stirred at $100 \mathrm{rpm}$ for $15 \mathrm{~min}$. Approximately $4 \mu \mathrm{L}$ of $2 \%$ APTES in AR grade ethanol was reacted with dried GCE-OH for $2 \mathrm{~h}$. The electrode was washed with ethanol to remove excess APTES and byproducts, blown by nitrogen gas flow, and dried for $3 \mathrm{~h}$. The amine functionalized GCE $\left(\mathrm{GCE}-\mathrm{NH}_{2}\right)$ was incubated for $6 \mathrm{~h}$ in a cocktail of $0.5 \mathrm{mg}$ dibenzocyclooctyne $\mathrm{N}$-hydroxysuccinimidyl ester (DBCO-NHS) and $0.25 \mathrm{mg}$ $N$-(dimethylaminopropyl)- $N^{\prime}$-carbodiimidehydro chloride) in $1 \mathrm{~mL}$ ethanol (ACS grade). After $6 \mathrm{~h}$, the electrode was removed from the solution and washed thoroughly with ethanol three times and air dried. The concentration of $\mathrm{N}$-(2-azidoacetyl)-oxytocin (OT-AZ) was measured using Thermofisher Scientific spectrophotometer (Model: Nanodrop One/One ${ }^{\mathrm{c}}$ ) and diluted with the stock solution to get the desired concentration. GCE-DBCO was incubated for $12 \mathrm{~h}$ in $0.1 \mathrm{M}$ phosphate buffer solution (PBS) at $\mathrm{pH} 7.0$ containing $50 \mu \mathrm{M}$ of OT-AZ. After the incubation, the OT-coated electrode was washed with PBS buffer and dried under nitrogen gas.

\subsection{Electrochemical Impedance Studies}

Electrochemical impedance studies were conducted using a Biologic potentiostat, model SP-300. The EIS measurements were conducted in the 3-electrode system consists of glassy carbon electrode (GCE) as working electrode and $\mathrm{Ag} / \mathrm{AgCl}(\mathrm{Sat} . \mathrm{KCl}$ ) as reference electrode and spiral platinum wire as counter electrode. All EIS measurements were carried out in room temperature at half-wave peak potential $(0.210 \mathrm{~V})$ of the redox mixture in phosphate buffer solution $(100 \mathrm{mM}, \mathrm{pH} 10.0)$ containing a mixture of $5 \mathrm{mM}\left[\mathrm{Fe}(\mathrm{CN})_{6}\right]^{4-}$ and $5 \mathrm{mM}\left[\mathrm{Fe}(\mathrm{CN})_{6}\right]^{3-}$. The AC frequency was scanned, ranging from $100 \mathrm{kHz}$ to $0.01 \mathrm{~Hz}$ with excitation amplitude of $10 \mathrm{mV}$. The change in charge transfer resistance $\left(\mathrm{R}_{\mathrm{CT}}\right)$ at electrode/electrolyte interface was investigated using the EIS technique.

\section{Results and Discussion}

\subsection{Job's Plot}

The stoichiometric ratio of coordination complex between $\mathrm{OT}$ and $\mathrm{Cu}^{2+}$ was studied at $\mathrm{pH} 10.0$ using Job's plot [14]. The method is well known for quantifying stoichiometry of host-guest molecules based on the spectral changes observed. The UV-visible absorbance spectra of the coordination complexes with different ratio of the metal ion $\left(\mathrm{Cu}^{2+}\right)$ were recorded. Figure 2 shows the plot between absorbance and molar fraction of the $\mathrm{Cu}^{2+}$ ion $\left(f_{m}=\left[\mathrm{Cu}^{2+}\right] /[\mathrm{OT}]+\left[\mathrm{Cu}^{2+}\right]\right)$. The stoichiometry of coordination complex formed was determined from Job's plot according to Equation (1):

$$
n=\frac{f_{\text {peak }}}{1-f_{\text {peak }}}
$$

The plot (Figure 2) shows the $f_{\text {peak }}$ value at 0.5 and, on substituting the value in Equation (1), the coordination ratio of OT-Cu${ }^{2+}$ complex is $1: 1$. The ratio unveils that there could be only one $\mathrm{Cu}^{2+}$ ion coordinating with one molecule of OT. We postulated intermolecular interactions of OT to $\mathrm{Cu}^{2+}$ at $\mathrm{pH} 7.0$, where more than one $\mathrm{OT}$ is involved in the coordination with one $\mathrm{Cu}^{2+}$. The titrations at $\mathrm{pH} 10.0$ further prove different binding mechanisms between OT and $\mathrm{Cu}^{2+}$ from $\mathrm{pH}$ 7.0. 


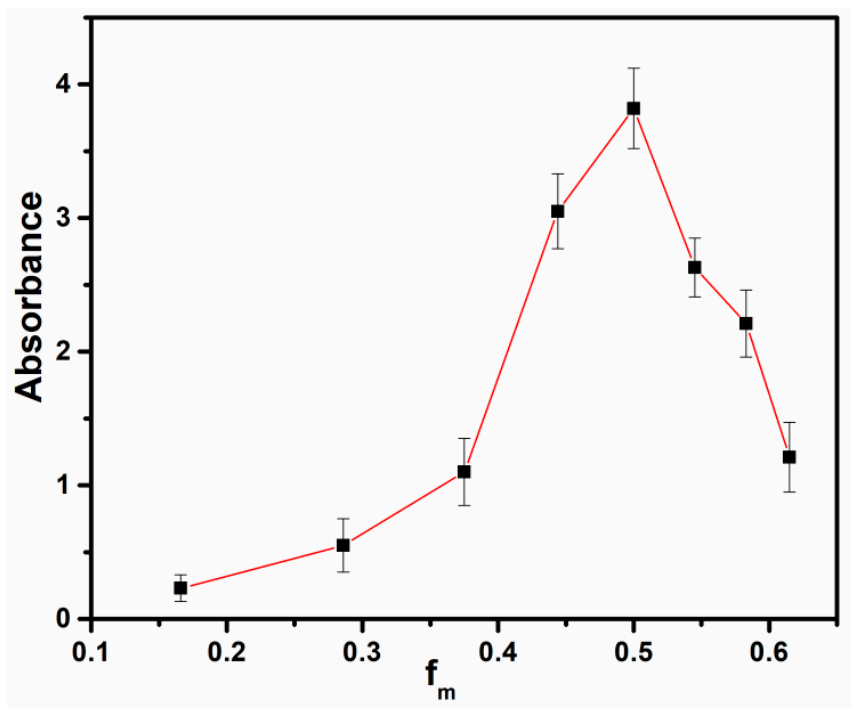

Figure 2. Jobs plot showing $f_{\text {peak }}$ at 0.5 reveals 1:1 coordination complex between Oxytocin and $\mathrm{Cu}^{2+}$. Error bars represent the standard deviation calculated from three repetitive experimental results.

\subsection{Impedimetric Detection of $\mathrm{C} u^{2+}$}

In our previous report [11], we reported the high affinity of OT towards $\mathrm{Zn}^{2+}$ and $\mathrm{Cu}^{2+}$ (at $\left.\mathrm{pH} 7.0\right)$ among the various metal ions, but we could not discriminate between the two without the use of masking agents. It is proven that, although the binding mechanism for $\mathrm{Zn}$ and $\mathrm{Cu}$ is different, the binding affinity in pH 7.0 is similar. We harnessed the difference in the binding mechanism to enable selectivity toward $\mathrm{Cu}^{2+}$ and decided to evaluate the effect of $\mathrm{pH}$ on selectivity. Impedimetric sensing of $\mathrm{Zn}^{2+}$ and $\mathrm{Cu}^{2+}$ ions $(1 \mathrm{nM})$ was conducted after incubating in the respective ion solution at $\mathrm{pH} 7.0$ and $\mathrm{pH} 10.0$ (Figure 3). The sensor signal is presented as the normalized charge transfer resistance $\left(R_{C T}\right)$, which is calculated as the ratio between $R_{C T}$ for the concentration of $M^{2+}\left(R_{C T}\left(C_{i}\right)\right.$ and blank solution $\left(\mathrm{R}_{\mathrm{CT}}\left(\mathrm{C}_{0}\right)\right)$ of the sensor. Our study shows that, at $\mathrm{pH} 7.0$, there is significant response from the OT sensor, both to $1 \mathrm{nM} \mathrm{Zn}^{2+}$ and to $1 \mathrm{nM} \mathrm{Cu}^{2+}$. However, the response of OT sensor towards $\mathrm{Cu}^{2+}$ and $\mathrm{Zn}^{2+}$ at $\mathrm{pH} 10.0$ is very different. At $\mathrm{pH}$ 10.0, no significant signal was observed in the presence of $1 \mathrm{nM} \mathrm{Zn}^{2+}$. By contrast, the response for $1 \mathrm{nM} \mathrm{Cu}^{2+}$ was enhanced in comparison to that at pH 7.0.

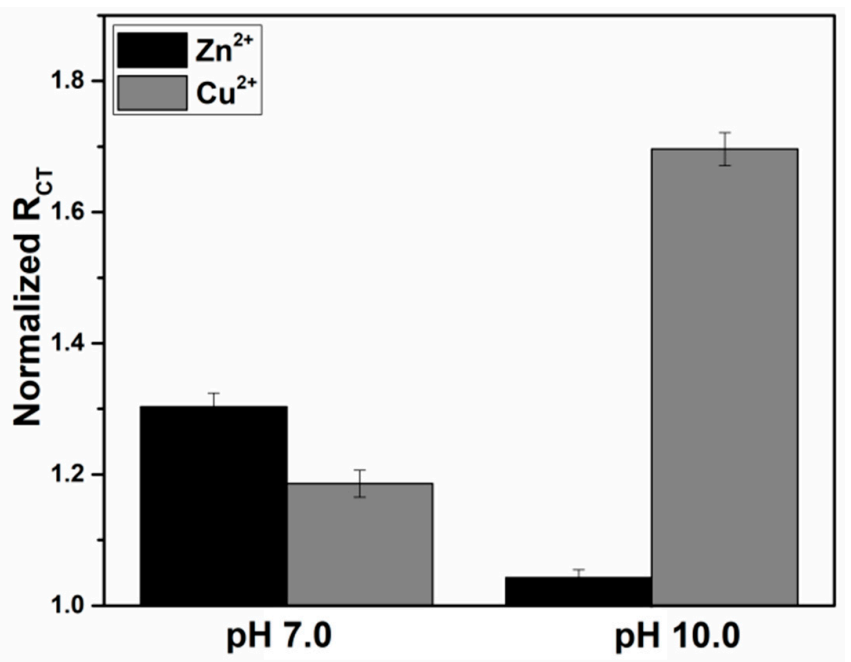

Figure 3. Histograms showing the sensor response to $1 \mathrm{nM} \mathrm{Zn}^{2+}$ and $\mathrm{Cu}^{2+}$ at $\mathrm{pH} 7.0$ and $\mathrm{pH} 10.0$. Selective detection of $1 \mathrm{nM} \mathrm{Cu}^{2+}$ at $\mathrm{pH} 10.0$ and negligible response from $1 \mathrm{nM} \mathrm{Zn}^{2+}$ at the same $\mathrm{pH}$. 
The results provide strong evidence to support our hypothesis that metal detection is governed by the binding mechanism. Since the ligation of $\mathrm{Zn}^{2+}$ to OT takes places through carbonyl oxygens, while $\mathrm{Cu}^{2+}$ chelation of OT takes place through deprotonated nitrogens of amide, the $\mathrm{pH}$ plays a crucial role in the binding. At $\mathrm{pH}$ 10.0, the deprotonation of amides is more favorable and, hence, increases the affinity towards $\mathrm{Cu}^{2+}$. We assume that the lack of affinity towards $\mathrm{Zn}^{2+}$ at $\mathrm{pH} 10.0$ results from the preferred formation of zinc hydroxide and the conformational changes associated with the electrostatic repulsions of the deprotonated amides.

After the confirmation of selective detection of $\mathrm{Cu}^{2+}$ at $\mathrm{pH} 10.0$ using the OT sensor, the sensor response towards various $\mathrm{Cu}^{2+}$ concentrations was studied. The OT sensor was exposed to increasing concentrations of $\mathrm{Cu}^{2+}$, ranging from $1 \mathrm{pM}$ to $0.1 \mu \mathrm{M}$, and the corresponding impedance spectra were recorded. The obtained Nyquist plots are shown in Figure 4A. The gradual increase in the diameter of the semicircle with the increase in $\mathrm{Cu}^{2+}$ concentration represents an increase in the $\mathrm{R}_{\mathrm{CT}}$ attributed to the metal ion binding. Figure 4B presents the logarithmic concentration of $\mathrm{Cu}^{2+}$ versus normalized $R_{C T}$. The sensor shows the linear correlation between the $\mathrm{R}_{\mathrm{CT}}$ and $\mathrm{Cu}^{2+}$ over a wide range of concentrations- $1 \mathrm{pM}$ to $0.1 \mu \mathrm{M}$-with an enhanced sensitivity of $0.16 \mathrm{M}^{-1}$ in comparison to that at $\mathrm{pH} 7.0$ [11]. We assume that high $\mathrm{pH}$ facilitates the deprotonation of amide nitrogens and makes coordination bonding between OT and $\mathrm{Cu}^{2+}$ stronger. The detection limit of the OT sensor for $\mathrm{Cu}^{2+}$ sensing was determined according to the formula: $\mathrm{LOD}=[(3.3 \times \mathrm{S} . \mathrm{D})-\mathrm{a}] / \mathrm{b}$, where S.D is the standard deviation of the blank, $a$ is the linear coefficient, and $b$ is the sensitivity. The calculated LOD is found to be $2.65 \times 10^{-13} \mathrm{M}$.
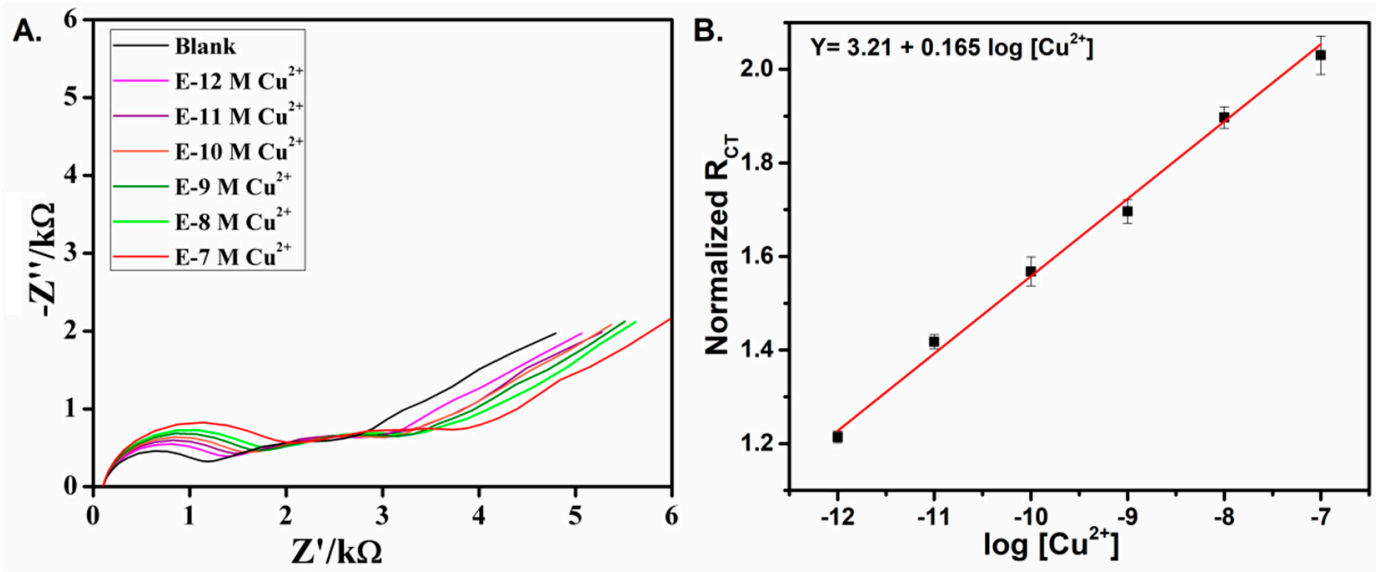

Figure 4. (A) Nyquist plots obtained for that OT Sensor in $5 \mathrm{mM}\left[\mathrm{Fe}(\mathrm{CN})_{6}\right]^{3-/ 4-}$ consists of $0.1 \mathrm{M}$ phosphate buffer solution (PBS) at $\mathrm{pH} 10.0$ after incubation in various $\mathrm{Cu}^{2+}$ concentrations and (B) logarithmic concentration of $\mathrm{Cu}^{2+}$ vs. normalized charge transfer resistance $\left(\mathrm{R}_{\mathrm{CT}}\right)$.

\section{Conclusions}

Peptides are natural metal chelators and serve as attractive sensing elements. The unique combination of functional groups and conformational flexibility determines the peptide's metal binding mechanism. We showed here that we can harness the differences in binding mechanisms of OT toward metal ions to achieve enhanced selectivity. We relied on the deprotonation-assisted OT-Cu binding mechanism and showed that using a high $\mathrm{pH}$ in the sensing media significantly increases the affinity of the sensor toward copper compared to using $\mathrm{pH}$ 7.0. Furthermore, we proved that we can selectively determine $\mathrm{Cu}^{2+}$ in the presence of $\mathrm{Zn}^{2+}$ at $\mathrm{pH} 10.0$ without using masking agents. This study suggests that relying on the unique mechanisms of peptide metal interactions can be used for enhancing sensitivity and increase the selectivity of sensors by rational design. We believe that this approach might be very important for other peptide-based sensors for metal ions and other analytes. 
Author Contributions: K.K.T., M.H., and S.Y. conceived and designed the experiments; I.A. synthesized the azido-OT; K.K.T. and I.A. performed the experiments and all the authors discussed the work; K.K.T. wrote the paper. M.H. and S.Y. supervised the work.

Funding: This project has received funding from the European Union's Horizon 2020 research and innovation programme under grant agreement No. 664786.

Acknowledgments: The authors would like to thank RECORD-IT project. S.Y. would like to thank the the Binjamin H. Birstein Chair in Chemistry.

Conflicts of Interest: The authors declare no conflict of interest.

\section{References}

1. Wu, C.M.; Lin, L.Y. Immobilization of metallothionien as a selective biosensor chip for the detection of metal ions by surface plasmon resonance. Biosens. Bioelectron. 2004, 20, 864-871. [CrossRef] [PubMed]

2. Yang, W.; Edith, C.; Gary, D.W.; Hibbert, D.B.; Gooding, J.J. Exploring the use of the tripeptide Gly-Gly-his as a selective recognition element for the fabrication of electrochemical copper sensors. Analyst 2002, 128, 712-718. [CrossRef]

3. Chow, E.; Goading, J.J. Peptide modified electrodes as electrochemical metal ion sensors. Electroanalysis 2006, 18, 1437-1448. [CrossRef]

4. Bontidean, I.; Berggren, C.; Johansson, G.; Csöregi, E.; Mattiasson, B.; Lloyd, J.R.; Jakeman, K.J.; Brown, N.L. Detection of heavy metal ions at femtomolar levels using protein-based biosensors. Anal. Chem. 1998, 70, 4162-4169. [CrossRef] [PubMed]

5. Johnson, A.M.; Holcombe, J.A. Poly(L-cysteine) as an electrochemically modifiable ligand for trace metal chelation. Anal. Chem. 2005, 77, 30-35. [CrossRef] [PubMed]

6. Mervinetsky, E.; Alshanski, I.; Hamo, Y.; Sandonas, L.M.; Dianat, A.; Buchwald, J.; Gutierrez, R.; Cuniberti, G.; Hurevich, M.; Yitzchaik, S. Copper Induced Conformational Changes of Tripeptide Monolayer Based Impedimetric Biosensor. Sci. Rep. 2017, 7, 9498. [CrossRef] [PubMed]

7. Godwin, H.A.; Berg, J.M. A fluorescent zinc probe based on metal-induced peptide folding. J. Am. Chem. Soc. 1996, 118, 6514-6515. [CrossRef]

8. Szunyogh, D.; Gyurcsik, B.; Larsen, F.H.; Stachura, M.; Thulstrup, P.W.; Hemmingsen, L.; Jancsó, A. Zn ${ }^{\mathrm{II}}$ and $\mathrm{Hg}^{\mathrm{II}}$ binding to a designed peptide that accommodates different coordination geometries. Dalton Trans. 2015, 44, 12576-12588. [CrossRef] [PubMed]

9. Marx, G.; Gilon, C. The Molecular Basis of Memory. Part 2: Chemistry of the Tripartite Mechanism. ACS Chem. Neurosci. 2013, 4, 983-993. [CrossRef] [PubMed]

10. Liu, D.; Seuthe, A.B.; Ehrler, O.T.; Zhang, X.; Wyttenbach, T.; Hsu, J.F. Oxytocin-Receptor Binding: Why Divalent Metals Are Essential. J. Am. Chem. Soc. 2005, 127, 2024-2025.

11. Tadi, K.K.; Alshanksi, I.; Mervinetsky, E.; Marx, G.; Petrou, P.; Dimitrios, K.M.; Gilon, C.; Hurevich, M.; Yitzchaik, S. Oxytocin-Monolayer-Based Impedimetric Biosensor for Zinc and Copper Ions. ACS Omega 2017, 2, 8770-8778. [CrossRef] [PubMed]

12. Wyttenbach, T.; Liu, D.; Bowers, M.T. Interactions of the hormone oxytocin with divalent metal ions. J. Am. Chem. Soc. 2008, 130, 5993-6000. [CrossRef] [PubMed]

13. Jewett, J.C.; Bertozzi, C.R. Cu-free click cycloaddition reactions in chemical biology. Chem. Soc. Rev. 2010, 39, 1272-1279. [CrossRef] [PubMed]

14. Renny, J.S.; Tomasevich, L.L.; Tallmadge, E.H.; Collum, D.B. Method of Continuous Variations: Applications of Job Plots to the Study of Molecular Associations in Organometallic Chemistry. Angew. Chem. Int. Ed. Engl. 2013, 52, 11998-12013. [CrossRef] [PubMed]

(C) 2018 by the authors. Licensee MDPI, Basel, Switzerland. This article is an open access article distributed under the terms and conditions of the Creative Commons Attribution (CC BY) license (http:/ / creativecommons.org/licenses/by/4.0/). 